\title{
Results of Covert Investigative Actions and Operational Investigative Measures Related to Temporary Interference in Private Communication: Problem Issues of Use in Criminal Proceedings
}

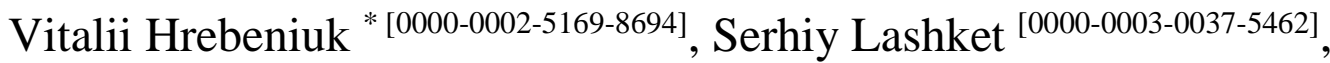 \\ Leonid Shcherbyna [0000-0002-1607-8174]
}

National Academy of Security Service of Ukraine, Kyiv, Ukraine

*ratel6969@meta.ua

\begin{abstract}
Compliance with the set of requirements for the legality of temporary interference in a person's private life by the authorized bodies of the state is one of the urgent scientific problems related to the protection of legitimate interests, human rights and freedoms. The use of covert methods of gathering information necessary to ensure state security, public order and solve the problems of criminal proceedings is a well-established practice of both domestic and foreign law enforcement agencies and special services. In view of this, the issue of the effectiveness of the use of results obtained through the temporary restriction of human rights during covert investigative (search) actions and operational and investigative measures, especially those related to interference in private communication, in criminal proceedings is particularly relevant. It is stated that in Ukraine the activities of authorized state bodies in the field of temporary restriction of human rights and freedoms are strictly regulated, and the use of the results of covert investigative (search) actions and operational and investigative measures related to interference in private communication in criminal proceedings, is properly controlled. At the same time, today only a relatively small number of results of interference in private communication, compared to the total number of taken covert actions and measures, are used as evidence in criminal proceedings. The study helped to identify a number of shortcomings that negatively affect the use of the results obtained during the implementation of such covert actions and measures, and to develop proposals for possible ways to eliminate these obstacles to solving the problems of criminal proceedings.
\end{abstract}

Keywords: interference in private communication, covert investigative actions, operative-investigative measures, use of results, criminal proceedings, evidence

\section{INTRODUCTION}

Today, the need to use the results of covert methods of gathering information related to interference in a person's private communication arises due to their importance for criminal proceedings.

The possibility of using such methods in pre-trial investigation is provided not only in domestic law, but also in certain international legal acts, in particular, Recommendation № Rec (2005) 10 of the Committee of Ministers of the Council of Europe «On "special methods of investigation" of serious crimes, including terrorist acts» from 20.04.2005. This Recommendation recommends to EU Member States to improve criminal policy and national legislation in such a way as to allow the use of covert methods of investigation and make them available to the competent authorities to the extent necessary in a democratic society for effective criminal investigation and prosecution [1].

Domestic legislation provides the possibility of using such methods of investigation in the form of covert investigative actions (hereinafter - CIA) or operational and investigative measures (hereinafter - OIM). Their varieties, which are associated with interference in private communication, are audio and video surveillance of a person; arrest, inspection and seizure of correspondence; removal of information from transport telecommunication networks; removal of information from electronic information systems. 
Mentioned CIA, in accordance with Part 2 of Art. 246 of the Criminal Procedure Code of Ukraine (CPC of Ukraine), are conducted exclusively in criminal proceedings for serious or particularly serious crimes, if information about the crime and the person who committed it, cannot be obtained in any other way [2], and OIM, in accordance with p. 9, 10 st. 8 of the Law of Ukraine "On operational and investigative activities" are used solely to prevent the commission of a serious or especially serious crime, prevention and cessation of terrorist acts and other encroachments of special services of foreign states and organizations, if otherwise impossible to obtain information [3].

In view of the above, their results in criminal proceedings can be used as fully as possible, not limited to evidence. However, due to a number of factors, the use of such results in some proceedings is extremely difficult, which requires research on this issue to find possible ways to solve it, which actualized the direction of scientific research and the chosen topic of publication.

\section{RESEARCH METHODOLOGY}

The study was conducted with the methods selected according to its purpose, objectives, object and subject. The study is based on the dialectical method of scientific knowledge of real phenomena and processes. A number of special methods were also used, which are means of scientific research in the arsenal of legal sciences, in particular: system-structural - allowed to reveal the concept and content of covert methods of investigation, which are conducted in the form of CIA and OIM, which are associated with interference in private communication; comparative law - used in the analysis of legislation and bylaws, materials of criminal proceedings, operational and investigative activities and judicial practice; formal-logical - helped to identify contradictions between the conceptual apparatus of regulations governing the conduct of CIA and OIM, related to interference in private communication; sociological and statistical - used to process relevant data on research issues; interpretations and generalizations to formulate the conclusions of the study. These methods were used in the relationship and interdependence, which ensured the comprehensiveness, completeness and objectivity of the study.

\section{RESULTS OF THE RESEARCH}

The use of covert investigative methods in criminal proceedings involving interference with private communication has a long history, characterized by quite different, sometimes polar, approaches to this issue depending on the historical stage of development of the state and society. Thus, in the second half of the twentieth century the collection of evidence during the pre-trial investigation in modern Ukraine was carried out only from open sources, and in the scientific literature the prevailing opinion was that the results of covert methods of obtaining information can not be used in evidence. An obstacle in this way was that information about the fact and methods of conducting OIM was a state secret, and the possibility of declassification of the results obtained during their implementation was not provided. The use of the OIM results related to interference with private communication in criminal proceedings was exceptional at the time, and their pre-trial investigation and trial were carried out in compliance with the requirements for the protection of state secrets. Such legal regulation and the practice of using the OIM results related to interference in private communication in criminal proceedings persisted in Ukraine until 2001.

During 2001 - 2004, during the so-called "small judicial reform", the CPC of Ukraine in 1960 [4] supplemented Art. 187, 187-1, in accordance with the provisions of which the procedure for conducting such investigative (search) actions (hereinafter - ISA) as removal of information from communication channels, seizure of correspondence, its inspection and seizure was regulated in criminal proceedings. Also, this Code was amended to recognize the protocols with the relevant annexes, drawn up as a result of individual OIM, as an independent source of evidence. In turn, Part 2 of Art. 8 of the Law of Ukraine "On operational and investigative activities" regulated the provisions according to which secret intrusion into the home or other property of a person, removal of information from communication channels, control of correspondence, telephone conversations, telegraph and other correspondence, use of other technical means information was carried out only by court decision. Such OIM were conducted solely for the purpose of preventing crime or finding out the truth during the pre-trial investigation, if it is not possible to obtain information in any other way. As a result of their implementation, a protocol with the relevant annexes was drawn up, which was to be used in criminal proceedings as a source of evidence.

The novelties introduced into the mentioned laws were negatively perceived by both scientists and practitioners, as their norms did not stipulate requirements for the form and content of such protocols, the procedure for compiling, submitting to pre-trial investigation and court bodies, etc. [5, p. 57-62]. These shortcomings, and only partially, were subsequently eliminated due to the resolution of the Cabinet of Ministers of Ukraine dated 26.11.2007 № 1169 "On the procedure for obtaining a court permit for measures that temporarily restrict human rights and the use of information obtained", which contributed to further development of legal regulation of the use in criminal proceedings of the results obtained through covert methods of investigation [6].

Further improvement of legal regulation in this area formed the preconditions for the "proceduralization" of 
OIM and the introduction of the institute of CIA in the CPC of Ukraine in 2012.

Part 4 of Art. 258 of the CPC of Ukraine in 2012 for the first time in domestic law defined the concept of "interference in private communication" which means access to the content of communication, if participants have sufficient grounds to believe that it is private.

This Code also regulates the types of such interference, procedural issues of granting permission to conduct and the procedure for the implementation of relevant actions and measures. The organizational issues are regulated by the Instruction on the organization of covert investigative (search) actions and use of their results in criminal proceedings, approved by the order of the Prosecutor General's Office of Ukraine, the Ministry of Internal Affairs of Ukraine, the Security Service of Ukraine, the Administration of the State Border Guard Service of Ukraine, the Ministry of Finance of Ukraine, the Ministry of Justice of Ukraine dated 16.11.2012 №114 / 1042/516/1199/936/1681/51 ( hereinafter - the Instruction 2012) [7], and the provisions of a number of departmental regulations that are classified or of restricted access.

In turn, in accordance with Part 2 of Art. 99 of the CPC of Ukraine, materials containing factual data on illegal actions of individuals and groups of persons collected by operational units in compliance with the Law of Ukraine "On operational and investigative activities", subject to the requirements of this article, were recognized as documents and could be used in criminal proceedings as evidence. This rule fully applies to the results obtained during the OIM, which are associated with interference in private communication.

Based on the results of the CIA, protocols are drawn up, to which, if necessary, appendices are attached, which are submitted to the prosecutor no later than 24 hours after their termination (Part 1 of Article 252 of Ukraine). The Instruction of 2012 stipulates that the protocols on such actions and annexes to them, the application for permission to conduct CIA and the decision of the investigating judge on permission to conduct, containing information about the fact and methods of their implementation, as well as information that allows to identify the person, place or thing in respect of which such an action is carried out or is planned to be carried out, the disclosure of which may endanger national interests and security, is a subject to secrecy. Classification of such material storage media (hereinafter - MSM) is carried out by the investigator, prosecutor, operative of the authorized operational unit, investigating judge by providing on the basis of the Code of information constituting a state secret, the relevant document classified [8].

After completion of the CIA, the declarations of secrecy of the MSM on their implementation are subject to declassification on the basis of the decision of the prosecutor - procedural manager of the pre-trial investigation in a particular criminal proceeding. Such a decision is made taking into account the circumstances of the proceedings and the need to use the results obtained as evidence after such actions, provided that the disclosure of this information will not harm the national security of Ukraine. Declassified MSM on conducting CIA are deregistered in a regime-secret body and attached to the materials of criminal proceedings in accordance with the procedure established by the CPC of Ukraine.

The results of the CIA (OIM) related to the interference with private communication can be used in criminal proceedings to make appropriate procedural decisions, apply enforcement measures, precautionary measures, conduct CIA, such as temporary access to things and documents, impose seizure of property, search, inspection, location of wanted persons, and their detention, etc.

However, the main purpose of their implementation is to obtain information about a serious or particularly serious crime and the person who committed it, or, alternatively, to obtain factual data on the basis of which it is possible to establish the presence or absence of facts and circumstances relevant to criminal proceedings and are subject to proof.

Disadvantages include the relatively small number of results of CIA (OIM) related to interference in private communication that are used as evidence in criminal proceedings (compared to the total number of such taken actions and measures).

This, on the one hand, is due to the fact that the expected results are not always obtained, and the information obtained that does not relate to the pre-trial investigation is immediately destroyed (Part 1 of Article 255 of the CPC of Ukraine). On the other hand, some of the information transmitted for use in criminal proceedings is not recognized as evidence due to shortcomings in recording the progress and results of the CIA (OIM), violation of the procedural deadlines for their transfer to the prosecutor or imperfect declassification procedure.

For example, in accordance with Part 3 of Art. 252 of the CPC of Ukraine protocols on carrying out CIA with appendices not later than in 24 hours from the moment of the termination of the specified actions are transferred to the prosecutor.

However, according to paragraph 4.3 of the Instruction 2012, the protocol on the results of the CIA with annexes no later than 24 hours after its preparation is submitted to the prosecutor, who supervises compliance with the law during the pre-trial investigation in the form of procedural guidance. The comparison of 
the given legal norms indicates their collision, inconsistency.

According to the explanation of the Ministry of Justice of Ukraine, in case of contradiction between acts adopted by different bodies in the hierarchical structure higher and lower, the act adopted by the higher body is used as one that has greater legal force [9].

That is, in this case it is necessary to be guided by norm of h. 3 Art. 252 of the Criminal Procedure Code of Ukraine. However, several protocols may be drawn up during the term of the CIA, for example, during the arrest, inspection and seizure of correspondence (Part 4 of Article 262 of the CPC of Ukraine). In view of such circumstances, the question arises as to the moment of their transfer to the prosecutor - after the drawing up of the report or the end of the said action? The answer to this can be provided by editorial clarification as the norm of Art. 252 of the CPC of Ukraine, and the relevant provision of the Instruction 2012

In the event that the protocol is drawn up later than the statutory deadline, a natural question arises as to whether the terms of the CIA have been met and, as a consequence, whether they are admissible evidence. Sometimes such procedural documents are signed by unauthorized persons, for example, protocols for the withdrawal of information from transport telecommunications networks - employees of operational and technical units, despite the fact that this action was entrusted to the investigator, prosecutor to another operational unit.

In some cases, there are discrepancies in the content of the protocol on conducting CIA (OIM), related to interference in private communication, with the information recorded on the MSM, which serves as its annex. The above indicates the need to comply with the statutory procedural form of recording the progress and results of such CIA (OIM), which is a prerequisite for their further use in criminal proceedings.

MSM containing information obtained as a result of the CIA should be declassified as soon as possible, but not more than 10 days from the date of receiving a request from the prosecutor (paragraph 5.26 of the Instruction 2012).However, declassified materials sometimes arrive at the end of the pre-trial investigation, when the investigator is no longer able to use the results of the criminal proceedings, such as questioning the suspect about the facts and circumstances set out in the protocol or taking other actions that would reinforce the gathered evidence.

CIA and OIM involving interference in private communication are carried out in accordance with the classified decisions of the investigating judge on granting permission to hold it. In criminal proceedings where such CIA have been conducted, the defense often requests to review the grounds for their implementation and the relevant decision of the investigating judge on granting permission to conduct them. However, the provision of the Instruction of 2012 defines the procedure for declassification of the MSM for conducting CIA (protocols with annexes), and not for the decision of the investigating judge used by the defense to declare the results inadmissible evidence (Article 87 of the CPC of Ukraine).

This tactical approach of the defense is based on the provisions of Part 1 of Art. 87 of the CPC of Ukraine, according to which evidence is inadmissible if it is obtained as a result of significant violation of human rights and freedoms guaranteed by the Constitution and laws of Ukraine, international treaties, the binding nature of which has been approved by the Verkhovna Rada of Ukraine, as well as any other evidence obtained through information obtained as a result of a significant violation of human rights and freedoms. According to paragraph 1, part 2 of the same article, significant violations of human rights and fundamental freedoms include the implementation of procedural actions that require prior court permission, without such permission or in violation of its essential conditions.

This problem requires the answer to the following questions: What should be done if the prosecution does not have declassified CIA permits, cannot obtain them at all or receive them in time? Is it possible to say that in this case the relevant protocols with annexes must be declared inadmissible evidence in the proceedings?

\section{DISCUSSION OF RESULTS}

Judicial practice statistics show the dynamics of increasing cases of appeals against the actions of officials of pre-trial investigation bodies (prosecutors), related to the refusal to open to the defense of all materials of criminal proceedings related to CIA and OIM related to interference in private communication.

In its decisions, the Supreme Court of Ukraine drew attention to the following facts and stated that in accordance with the provisions of domestic law and case law of the European Court of Human Rights (ECHR), which is the source of law in Ukraine, there may be situations where CIA (OIM) protocols are open to the defense, and the permits for their conduct - no, because they can not be declassified on objective grounds, in accordance with the decision of the authorized entity. In some cases, such disclosure is possible later, after the transfer of proceedings to the court $[10 ; 11]$.

As can be seen from the content of these decisions of the Supreme Court, the decision of the investigating judge to grant permission to conduct CIA (OIM), related to interference in private communication, should not be considered as independent evidence. Evidence in criminal proceedings, in accordance with Art. 84 of the CPC of Ukraine, are factual data obtained in the manner prescribed by this Code, on the basis of which the 
investigator, prosecutor, investigating judge and court establish the presence or absence of facts and circumstances relevant to criminal proceedings and subject to proof, and their procedural sources are testimony, physical evidence, documents and expert opinions.

The decision of the investigating judge, which became the basis for the CIA or OIM, is not a document within the meaning of Part 2 of Art. 99 of the CPC of Ukraine, as it does not contain recorded and collected factual data on illegal actions of individuals or groups of persons. Therefore, such a decision on a permit to conduct an CIA or OIM is examined during the court proceedings, primarily in order to assess the admissibility of the evidence obtained as a result of these actions. In view of this, the Supreme Court has indicated that courts should not refuse to examine the protocols of the CIA (OIM) solely on the grounds that the materials do not contain permits, without clarifying the reason for such absence. The circumstances under which such permits were not disclosed to the defense at the stage of completion of the pre-trial investigation must be examined in detail by the court.

In the context of the above, some scientists rightly believe that it is legitimate for an authorized body to refuse to declassify MSM relating to particular CIA or OIM on the grounds that disclosure of this information would harm national security or other legally protected interests. This position is based on the decisions of the European Court of Human Rights in the cases "Leas v. Estonia" dated 06.03.2012, "Yakuba v. Ukraine" dated 12.02.2019 and "Doorson v. the Netherlands"of 26 March 1996, stating that the right to disclosure of all evidence is not absolute and may be restricted when it concerns the need to protect important public interests or to ensure the rights of others whose life, liberty or security may be endangered [12, p.161-162].

The opinion of domestic scientists about the need to get rid of the remnants of the past is correct. These remnants have existed since Soviet times, meaning that information about the fact and methods of covert actions and measures aimed at detecting, disclosing and investigating criminal offenses are a state secret. In view of this, it is proposed to refer such information to the secrecy of the investigation, and thus - to strengthen criminal liability for disclosure of these data, as for the disclosure of state secrets [13]. The implementation of this proposal is able to solve some of the problems that arise in the implementation of the above-mentioned CIA and OIM and the use of the results.

\section{CONCLUSIONS}

It was found that the problematic issues of using the results of CIA and OIM in criminal proceedings, related to interference in private communication, include shortcomings in recording their procedure and consequences, violation of procedural deadlines for transferring MSM to the prosecutor and imperfect declassification procedure. The elimination of these shortcomings should be facilitated by the adoption of measures aimed at improving the organizational and tactical issues of implementation of these actions and measures, as well as amendments to legislative and other legal acts in the part relating to their legal regulation. In particular, it is proposed:

- to supplement part 1 of Art. 246 of the CPC of Ukraine with the following sentence: "Responsibility for disclosure of information about the fact and methods of covert investigative (search) actions, except as provided by this Code, provided by the Criminal Code of Ukraine";

- to supplement part 3 of Art. 252 of the CPC of Ukraine with the sentence of the following content: "When such a protocol is drawn up before the termination of covert investigative (search) actions, it is handed over to the prosecutor not later than 24 hours after its drawing up";

- the Set of information constituting a state secret, approved by the order of the Central Department of the Security Service of Ukraine dated 23.12.2020 № 383, Instruction 2012 and other regulations must be brought in line with the proposed changes to attribute information on the fact and methods of CIA to the secrecy of the investigation, not to the state secret;

- to supplement Art. 387 of the Criminal Code of Ukraine parts 4 and 5, establishing the criminal liability for disclosure of information about the fact and methods of covert investigative (search) actions or operational search activities, except as provided by the CPC of Ukraine, and the same actions if they caused serious consequences, and determining the punishment as for the disclosure of a state secret.

The implementation of these proposals should help to increase the efficiency of the use of the results of CIA and OIM related to interference in private communication, criminal proceedings and pre-trial investigation of serious and especially serious crimes in general. 


\section{REFERENCES}

[1] Rekomendatsii № Rec (2005) 10 Komitetu Ministriv Rady Yevropy "Pro "osoblyvi metody rozsliduvannia" tiazhkykh zlochyniv, u tomu chysli terorystychnykh aktiv" [Recommendations № Rec (2005) 10 of the Committee of Ministers of the Council of Europe "On 'special methods of investigating' serious crimes, including terrorist acts"] vid 20.04.2005 r., available at: https://zakon.rada.gov.ua/laws/show/994_670\#Tex $\mathrm{t}$

[2] Kryminalnyi protsesualnyi kodeks Ukrainy [Criminal Procedure Code of Ukraine], Zakon Ukrainy № 4651-VI vid 13.04.2012 r. Vidomosti Verkhovnoi Rady Ukrainy, 2012, № 9-10, 11-12, 13 , st. $88, \quad$ available at: https://zakon.rada.gov.ua/laws/show/213512\#Text

[3] Zakon Ukrainy "Pro operatyvno-rozshukovu diialnist" [Law of Ukraine "On operational and investigative activities”] № 2135-XII vid 18.02.1992 r., Vidomosti Verkhovnoi Rady Ukrainy, 1992, № 22, st. 303, available at: https://zakon.rada.gov.ua/laws/show/213512\#Text

[4] Kryminalno-protsesualnyi kodeks Ukrainy [Criminal Procedure Code of Ukraine] (zi zminamy i dopovnenniamy), Zakon vid 28.12.1960 r. Vidomosti Verkhovnoi Rady URSR, 1961, № 2, st. 15, available at: https://zakon.rada.gov.ua /laws/show/1001-05\#Text

[5] Koziakov, I.M. (2003), Problemy teorii i praktyky zastosuvannia statei 187, 187-1 KPK Ukrainy [Problems of theory and practice of application of articles 187, 187-1 of the CPC of Ukraine: article], Pravo Ukrainy, № 4, ss. 57-62.

[6] Pro poriadok otrymannia dozvolu sudu na zdiisnennia zakhodiv, yaki tymchasovo obmezhuiut prava liudyny, ta vykorystannia dobutoi informatsii: postanova KM Ukrainy vid 26.09.2007 r. № 1169 [On the procedure for obtaining a court permit for the implementation of measures that temporarily restrict human rights and the use of extracted information: Resolution of the Cabinet of Ministers of Ukraine of September 26, 2007 № 1169], available at: https://zakon.rada. gov.ua/laws/show/1169-2007-\%D0\%BF\#Text

[7] Instruktsiia pro orhanizatsiiu provedennia nehlasnykh slidchykh (rozshukovykh) dii ta vykorystannia yikh rezultativ $u$ kryminalnomu provadzhenni [Instruction on the organization of covert investigative (search) actions and the use of their results in criminal proceedings]: nakaz Heneralnoi prokuratury Ukrainy, Ministerstva vnutrishnikh sprav Ukrainy, Sluzhby bezpeky Ukrainy, Administratsii Derzhavnoi prykordonnoi sluzhby Ukrainy, Ministerstva finansiv Ukrainy, Ministerstva yustytsii Ukrainy vid 16.11.2012 r. № 114/1042/516/1199/936/1681/51, available at: https://zakon.rada.gov.ua/laws/show/v011490012\#Text

[8] Zvid vidomostei, shcho stanovliat derzhavnu taiemnytsiu, zatverdzhenyi nakazom Tsentralnoho upravlinnia SB Ukrainy [The set of information that constitutes a state secret] vid 23.12.2020 r. № 383, available at: https://zakon.rada.gov.ua/laws/show /z0052-21\#Text

[9] Lyst Ministerstva yustytsii Ukrainy vid 26.12.2008 r. № 758-0-2-08-19 "Shchodo praktyky zastosuvannia norm prava u vypadku kolizii" [Letter of the Ministry of Justice of Ukraine dated December 26, 2008 № 758-0-2-08-19 "On the practice of applying the law in case of conflict"], available at: https://zakon.rada.gov.ua/laws/show/ v0758323-08\#Text

[10] Sprava № 751/7557/15-k, provadzhennia № 1337ks18: postanova Velykoi Palaty Verkhovnoho Sudu vid 16.01.2019 r. [Case № 751/7557/15-k, proceedings № 13-37x18: decision of the Grand Chamber of the Supreme Court of January 16, 2019.], available at: https://zakononline.com.ua /court-decisions/show/79298340

[11] Sprava № 640/6847/15-k, provadzhennia № 1343ks 19: postanova Velykoi Palaty Verkhovnoho Sudu vid 16.10.2019 r. [Case № 640/6847/15-k, proceedings № 13-43x19: decision of the Grand Chamber of the Supreme Court of 16.10.2019], available at: https://zakononline.com.ua/courtdecisions/show/85174578

[12] Pohoretskyi, M.A. and Sukhachova, I.O. (2020), Zastosuvannia nehlasnykh slidchykh (rozshukovykh) dii pry rozsliduvannia koruptsiinykh zlochyniv: okremi problemni pytannia [The use of covert investigative (investigative) actions in the investigation of corruption crimes: some problematic issues : article], Naukovyi visnyk Natsionalnoi akademii SB Ukrainy, no. 78, ss. 154-165.

[13] Antoniuk, Nataliia (2020), Vysnovky VS shchodo vidkryttia materialiv $N S(R) D$ u poriadku st. 290 KPK (sudova praktyka) [Conclusions of the Supreme Court on the opening of CIA materials in accordance with Art. 290 of the CPC (case law)], Zakon i biznes, 21.03-03.04.2020, available at: https://zib.com.ua/ua/141951-

praktika_vs_schodo_vidkrittya_materialiv_nsrd_v _poryadku_st2.html 